\title{
The chemokine receptor CXCR5 is pivotal for ectopic mucosa-associated lymphoid tissue neogenesis in chronic Helicobacter pylori-induced inflammation
}

\author{
Susann Winter • Christoph Loddenkemper • \\ Anton Aebischer • Katrin Räbel • Kirstin Hoffmann • \\ Thomas F. Meyer • Martin Lipp • Uta E. Höpken
}

Received: 14 April 2010 /Revised: 15 June 2010 / Accepted: 15 July 2010 /Published online: 27 August 2010

(C) The Author(s) 2010. This article is published with open access at Springerlink.com

\begin{abstract}
Ectopic lymphoid follicles are a key feature of chronic inflammatory autoimmune and infectious diseases, such as rheumatoid arthritis, Sjögren's syndrome, and Helicobacter pylori-induced gastritis. Homeostatic chemokines are considered to be involved in the formation of such tertiary lymphoid tissue. High expression of CXCL13 and its receptor, CXCR5, has been associated with the formation of ectopic lymphoid follicles in chronic infectious diseases. Here, we defined the role of CXCR5 in the development of mucosal tertiary lymphoid tissue and gastric inflammation in a mouse model of chronic $H$. pylori
\end{abstract}

\footnotetext{
S. Winter · K. Räbel • M. Lipp · U. E. Höpken

Department of Tumor Genetics and Immunogenetics,

Max Delbrück Center for Molecular Medicine (MDC),

Berlin 13125, Germany

C. Loddenkemper

Department of Pathology, Charité Medical University,

Berlin 12200, Germany

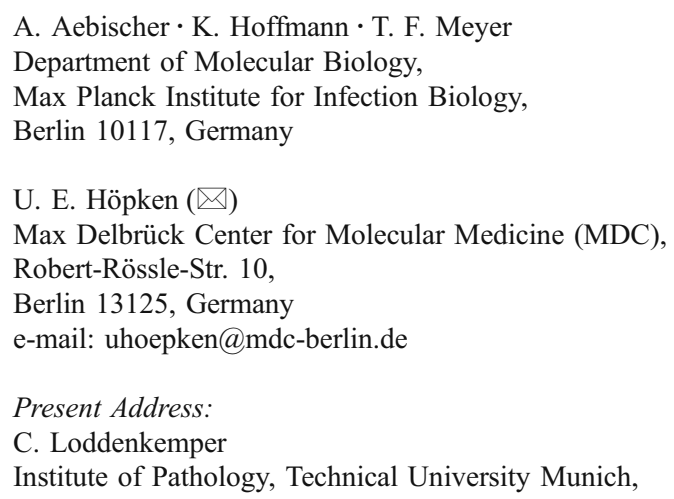

infection. CXCR5-deficient mice failed to develop organized gastric lymphoid follicles despite similar bacterial colonization density as infected wild-type mice. CXCR5 deficiency altered Th17 responses but not Th1-type cellular immune responses to $H$. pylori infection. Furthermore, CXCR5-deficient mice exhibited lower $H$. pylori-specific serum IgG and IgA levels and an overall decrease in chronic gastric immune responses. In conclusion, the development of mucosal tertiary ectopic follicles during chronic H. pylori infection is strongly dependent on the CXCL13/CXCR5 signaling axis, and lack of de novo lymphoid tissue formation attenuates chronic immune responses.

Keywords Chemokines · Tertiary lymphoid tissue $\cdot$ Chronic gastritis $\cdot$ Helicobacter pylori

\section{Introduction}

Chronic inflammatory diseases caused by autoimmune or pathogen-induced processes are often associated with the neogenesis of tertiary lymphoid tissues in non-lymphoid organs. These organized microstructures resemble conventional secondary lymphoid organs, with high endothelial venules, well-defined $\mathrm{B}$ and $\mathrm{T}$ cell zones, and specialized populations of differentiated stromal cells. The principal molecules mediating embryonic lymphoid organogenesis, i.e., inflammatory cytokines of the tumor necrosis factor/ lymphotoxin (LT) family and homeostatic chemokines, are also responsible for the complex sequence of events leading to de novo lymphoid tissue neogenesis [1-3]. Chemokine (C-X-C motif) ligand 13 (CXCL13) and its receptor 
CXCR5 have been linked to $\mathrm{B}$ cell recruitment in autoimmune diseases such as rheumatoid arthritis, multiple sclerosis, and experimental autoimmune encephalomyelitis, in humans and in animal disease models [4-8]. We recently provided direct evidence for a role of the homeostatic chemokines CXCL13, CCL19, and CCL21 in the formation of tertiary lymphoid tissues in a murine model of chronic antigen-induced arthritis [9]. Furthermore, ectopic transgenic expression of all three chemokines was sufficient to induce de novo lymphoid neogenesis [10-13]. Indirect evidence suggests that the same molecular mechanisms also trigger the formation of tertiary lymphoid tissues during chronic inflammation associated with infectious diseases, i.e., Lyme arthritis [14], hepatitis C-induced liver inflammation [15], Propriobacterium acnes [16], Mycobacterium tuberculosis $[17,18]$, and Helicobacter pylori infection [19, 20].

Chronic inflammation due to persistent $H$. pylori infection can give rise to organized tertiary lymphoid tissues in the gastric mucosa, also called mucosaassociated lymphoid tissue (MALT). MALT represents a premalignant condition that can eventually lead to gastric MALT lymphomagenesis in a small subset of chronically infected individuals. CXCL13 and its receptor, CXCR5, are highly expressed in reactive and/or malignant areas of lymphoid organization that develop in $H$. pylori-infected stomach mucosa of humans [20, 21] or in Helicobacter infection models in mice [22]. It was suggested that the CXCR5/CXCL13 signaling axis might be a key molecular regulator of tertiary lymphoid organ formation during the course of Helicobacter-induced gastritis. However, direct experimental evidence has yet to confirm this hypothesis. Therefore, we infected wild-type (Wt) and CXCR5deficient $\left(\mathrm{CXCR}^{-/}\right)$mice with the H. pylori strain Hp76 to investigate whether the effector function of de novo developed gastric lymphoid tissue contributes to the sequence and level of chronic infectious inflammation. CXCR5 deficiency leads to a complete lack of gastric tertiary lymphoid tissue formation and an overall reduction of chronic gastric inflammation. Thus, our results establish that $H$. pylori-induced formation of tertiary lymphoid tissues is crucially dependent on CXCL13/ CXCR5-mediated signaling events.

\section{Materials and methods}

Mice

CXCR5 knockout mice [23] were backcrossed with C57BL/6 mice for 12 generations. $\mathrm{CXCR}^{-/-}$and $\mathrm{C} 57 \mathrm{BL} / 6$ mice were raised under specific pathogen-free conditions and used at 2-3 months of age. All animal studies were performed according to institutional and state guidelines.

\section{H. pylori infection}

The mouse-adapted Hp76 strain of $H$. pylori [24] is a spontaneous streptomycin-resistant derivative of P49. The strain expresses VacA but is CagA negative [25] and was grown under microaerophilic conditions in brain heart infusion broth (Becton Dickinson) supplemented with $10 \%$ fetal calf serum (FCS), sodium bicarbonate $100 \mathrm{mM}$, streptomycin $400 \mu \mathrm{g} / \mathrm{ml}$, vancomycin $10 \mu \mathrm{g} / \mathrm{ml}$, nystatin $10 \mu \mathrm{g} / \mathrm{ml}$, and trimethoprim $2.5 \mu \mathrm{g} / \mathrm{ml}$. Mice were intragastrically inoculated with $2.5 \times 10^{8} \mathrm{CFU}$ H. pylori/100 $\mu \mathrm{l}$ phosphate buffered solution (PBS) after being fasted for $18 \mathrm{~h}$ on three successive occasions within a 6-day period. To confirm chronic infection with $H$. pylori, half of the stomach was homogenized, and bacterial colonization was determined by a plate-dilution method at indicated time points after infection. The second half of the stomach was processed for histological analysis. For the preparation of H. pylori lysate, bacteria were harvested from agar plates, suspended in PBS, sonicated for $90 \mathrm{~s}$ at $4^{\circ} \mathrm{C}$, and then centrifuged at $2,500 \times g$. The supernatant was harvested, and protein concentration was determined by Bradford assay.

Preparation of cell suspensions and proliferation assay

Spleen and mesenteric lymph node (mLN) cell suspensions were obtained by disruption of the organ in PBS/2\% FCS followed by hypotonic lysis to deplete red blood cells. For in vitro proliferation assays, $1 \times 10^{6}$ splenocytes or cells from the mLN were cultured in $200 \mu \mathrm{RPMI} / 10 \% \mathrm{FCS} /$ $10 \mathrm{U} / \mathrm{ml}$ interleukin (IL)-2 in the presence or absence of $100 \mu \mathrm{g} / \mathrm{ml} \mathrm{H}$. pylori lysate in 96-well round-bottom microtiter plates (in octuplicates) at $37^{\circ} \mathrm{C}$ for $72 \mathrm{~h}$. T cell proliferation was assessed by measuring the amounts of interferon- $\gamma$ (IFN- $\gamma$ ), IL-17, and IL-22 in culture supernatants by enzyme-linked immunosorbent assay (ELISA).

Enzyme-linked immunosorbent assay (ELISA)

For the assessment of $H$. pylori-specific serum antibody levels, microtiter plates were coated with $10 \mu \mathrm{g} / \mathrm{ml} H$. pylori lysate, and bound antibodies were detected with horseradish peroxidase (HRP)-conjugated antisera for IgG or IgA (Southern Biotechnology) in conjunction with 3,3',5,5'-tetramethylbenzidine (TMB) substrate. Sera were diluted 1:500 for $\operatorname{IgA}$ and 1:400 for $\operatorname{IgG}$ measurements, and the absorbance at $450 \mathrm{~nm}$ represents the relative antiH. pylori $\operatorname{IgG}$ or IgA value. All measurements were performed in duplicates, and the Ig levels from different mice were averaged. 
To quantitate serum cytokine levels or cytokine expression in culture supernatants, microtiter plates were coated with rat anti-mouse IFN- $\gamma$, rat anti-mouse IL-17, or rat anti-mouse IL-22 (all Biolegend). Bound cytokines were detected with biotinylated rat anti-mouse IFN- $\gamma$ (Becton Dickinson), biotinylated rat anti-mouse IL-17, or biotinylated rat anti-mouse IL-22 (both Biolegend), followed by HRP-conjugated streptavidin and TMB substrate. Recombinant mouse IFN- $\gamma$ (Becton Dickinson), IL-17, and IL-22 (Biolegend) served as standards. Serum was prepared from blood obtained by cardiac puncture and stored at $-80^{\circ} \mathrm{C}$.

Histological evaluation and immunohistology

The following primary antibodies were used: Alexa 488labeled rat anti-mouse CD3 (Biolegend), purified rat animouse CD138, and biotinylated rat anti-mouse B220 (Becton Dickinson), polyclonal rabbit anti-mouse CD3 and CD31 (Abcam), biotinylated rat anti-mouse F4/80 (Serotec), rat anti-mouse PNAd and rat anti-mouse follicular dendritic cell (FDC)-M1 (Becton Dickinson), rat anti-mouse Ki67 (Dako), biotinylated rat anti-mouse Foxp3 and Pacific Blue-labeled hamster anti-mouse CD11c (eBiosciences), and polyclonal rabbit anti- $H$. pylori (Dako). For paraffin sections, tissues were fixed in $4 \%$ phosphate-buffered formaldehyde, embedded in paraffin, cut into $5-\mu \mathrm{m}$ cross-sections, deparaffinized, and demasked by heat (citrate buffer, $\mathrm{pH}$ 6.0) or trypsinization (F4/80, PNAd). For cryosections, tissues were frozen in Tissue Tek OCT compound (Sakura Finetek), cut longitudinal into 5- to $8-\mu \mathrm{m}$ sections, fixed for $10 \mathrm{~min}$ in $-20^{\circ} \mathrm{C}$ acetone, and rehydrated in $50 \mathrm{mM}$ Tris-buffered saline, $\mathrm{pH}$ 7.6. Endogenous peroxidase activity was blocked with $3 \% \mathrm{H}_{2} \mathrm{O}_{2}$, and a biotinblocking step (Vector Laboratories) was performed before biotinylated antibodies were applied. Primary antibodies were incubated for $2 \mathrm{~h}$ at room temperature, followed by an appropriate secondary antibody or/and a streptavidin conjugate (alkaline phosphatase or HRP). Alkaline phosphatase activity was detected using Fast blue salt (SigmaAldrich). HRP activity was detected using the AEC detection system (Dako). All slides were mounted in Mowiol solution $(11.7 \% w / v$ Mowiol, 29.4\% $w / v$ glycerine, $0.12 \mathrm{M}$ Tris, $\mathrm{pH} 8.5$ ). Images were acquired with a Zeiss Axiophot fluorescence microscope with an Axiocam HRc camera and further processed using AxioVision 4.5 software (Carl Zeiss).

The intraepithelial lymphocytes were quantified in H\&E stained sections by counting the small and round lymphocytes within the basal portion of the surface epithelium and the gastric pits per 100 epithelial cells according to a previously published standard method used in routine pathology [26].

\section{Statistical analysis}

Results are expressed as arithmetic means \pm standard error of the mean (SEM). Values of $P<0.05$ were considered statistically significant and determined either by an unpaired, two-tailed Mann-Whitney or an unpaired, two-tailed Student's $t$ test, as indicated.

\section{Results}

H. pylori infectious status and inflammation

To assess the role of CXCR5 in the development of $H$. pylori-induced gastric inflammation and lymphoid tissue neogenesis, Wt and $\mathrm{CXCR}^{-/-}$mice were infected and monitored with respect to bacterial colonization and gastric inflammation (Fig. 1a-c). Colonization levels and pattern were comparable in $\mathrm{Wt}$ and $\mathrm{CXCR} 5^{-/-}$mice 5 to 7 months after inoculation with the mouse-adapted $H$. pylori strain Hp76 (Fig. 1b). In both groups, bacteria were found adherent to the surface of foveolar cells or between epithelial cells of the gastric mucosa (Fig. 1c). H. pylori was not detected in stomachs of uninfected animals (data not shown).

Histomorphological and immunohistochemical analysis was used to determine presence and phenotype of inflammatory infiltrates located in the submucosal and mucosal gastric tissue. Gastritis was graded according to the updated Sydney System [27]. The scoring system distinguishes between active neutrophil-dominated and chronic inflammation, characterized by the prevalence of macrophages, lymphocytes, and plasma cells. All inflammatory infiltrates were scored from 0 to 3 . Wt mice exhibited a strong active and a moderate chronic inflammation 7 months after infection. In contrast, $\mathrm{CXCR} 5^{-/-}$mice showed significantly reduced active inflammatory scores and only a minor reduction of the chronic inflammatory score (Table 1).

We observed the formation of one or multiple highly organized tertiary lymphoid tissues in chronically infected Wt mice (Fig. 2a and Table 1). Remarkably, the formation of ectopic lymphoid tissue was strongly abrogated in $\mathrm{CXCR}^{-/-}$mice (Fig. $2 \mathrm{~b}$ and Table 1). In only two out of $13 \mathrm{CXCR}^{-/-}$mice, loose lymphoid aggregates were visible (Fig. 2b). The majority of CXCR5 $5^{-/-}$ mice displayed less Ki67 staining, a marker for epithelial proliferation, in comparison to $\mathrm{Wt}$ mice, which showed pronounced Helicobacter-induced epithelial proliferation (Fig. 3a). Increase of intraepithelial lymphocytes ( $>25$ IELs/ 100 epithelial cells) and reactive epithelial changes including epithelial regeneration and/or hyperplasia were also scored. Both parameters were reduced in $\mathrm{CXCR} 5^{-/-}$mice compared to Wt animals (Table 1 and Fig. 3b). Taken together, 
Fig. 1 Comparable Helicobacter pylori gastric colonization in $\mathrm{Wt}$ and $\mathrm{CXCR} 5^{--}$mice. a Schematic representation of the experimental H. pylori infection model. b The degree of H. pylori colonization in the gastric mucosa of Wt (black squares; $n=7)$ and $\mathrm{CXCR} 5^{-1-}$ (open circles; $n=10$ ) mice was assessed by colony counting 5 and 7 months after infection. The degree of colonization was comparable 5 and 7 months after infection. Statistical significance was calculated by unpaired Mann-Whitney test. NS nonsignificant. c $H$. pylori specimen were also detected by immunohistochemical staining with an anti-H. pylori antiserum and hematoxylin counterstaining 7 months after infection (in red; examples indicated by arrows). A lower (upper panels) and higher magnification (lower panels) of each group is shown; scale bars, $100 \mu \mathrm{m}$
A

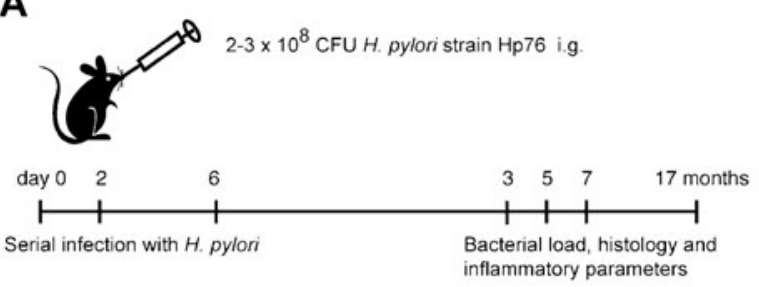

C
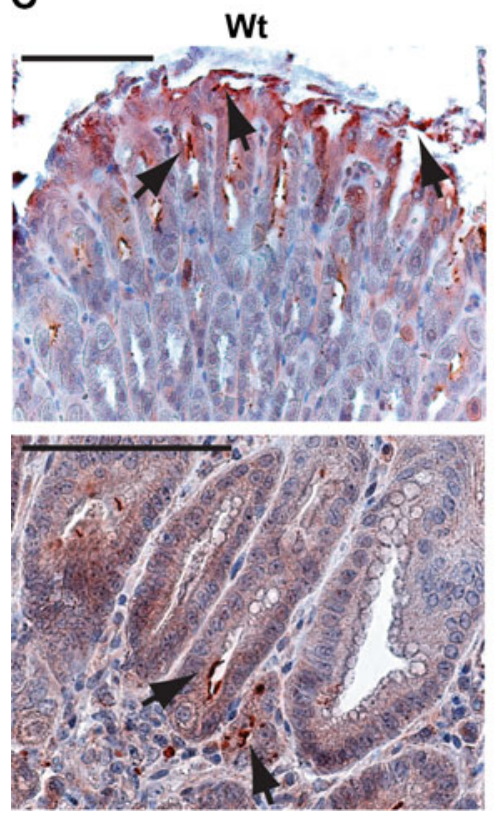

B

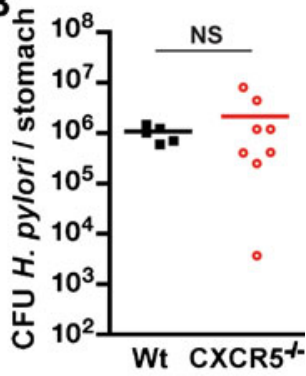

CXCR5 - -

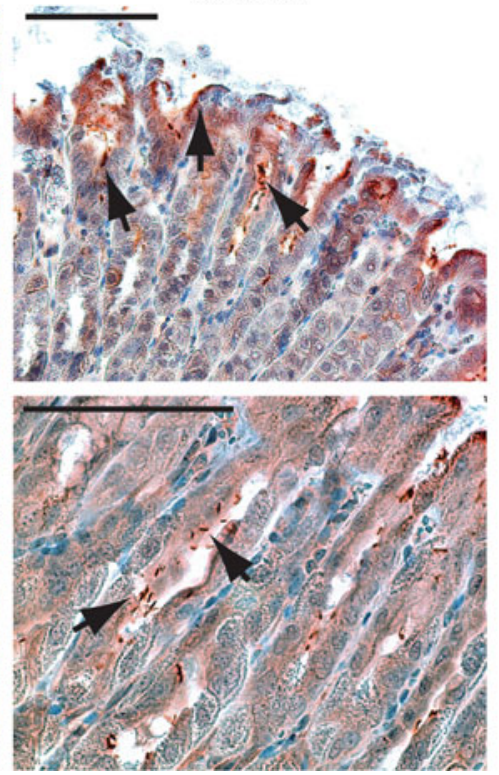

$\mathrm{CXCR5}^{-/-}$mice developed less active and chronic gastric inflammation than Wt controls (Table 1 and Fig. 3b).

Chronic infection with $H$. pylori causes the development of highly organized ectopic lymphoid structures in Wt but not in $\mathrm{CXCR5}^{-1-}$ mice

In Wt mice, tertiary lymphoid tissues developed fully within 5-7 months (Table 1) and displayed highly organized microstructures up to 17 months after infection (Figs. 4a and 5a-f; Table 1). This was strongly abrogated in H. pyloriinfected CXCR5 $5^{--}$mice (Fig. $4 \mathrm{~b}$ and Table 1). Eleven out of $13 \mathrm{CXCR}^{-/-}$mice analyzed showed no tertiary lymphoid tissue development (Table 1). In two cases $\left(\mathrm{CXCR}^{-1-}\right.$ No. 7 and No. 10, Table 1), an active chronic Helicobacter-induced inflammation was accompanied by loose cellular aggregates located in the submucosal and in the mucosal tissue. However, the cellular aggregates consisted mainly of macrophages and some scattered lymphocytes with an abundance of $\mathrm{CD} 31^{+}$blood vessels adjacent to these structures. No proper segregation into $\mathrm{T}$ and $\mathrm{B}$ cell zones and subsequently no formation of germinal centers (GCs) were observed in $\mathrm{CXCR}^{-/-}$mice (Fig. 4b).
Ectopic follicular structures, which developed regularly in infected Wt mice (Table 1), displayed discrete $\mathrm{T}$ cell and B cell areas characteristic of the compartmentalization exhibited by conventional lymphoid organs. In addition to macrophages scattered throughout the submucosal and mucosal tissue, small clusters of macrophages adjacent to follicular structures were observed. Within and adjacent to these lymphoid aggregates, an abundance of $\mathrm{CD} 1^{+}$blood vessels was detected (Fig. 4a). Detailed analysis of these highly structured lymphoid follicles revealed additional similarities to conventional LNs, i.e., a number of blood vessels expressed peripheral lymph node addressin (PNAd) and therefore were characterized as high endothelial venules (HEVs; Fig. 5a). These specialized HEVs allow lymphocyte extravasation from the blood and represent a specific feature of functional lymphoid organs. $\mathrm{CD}^{+} \mathrm{T}$ cell zones contained $\mathrm{CD}^{+}, \mathrm{CD}^{+}$(data not shown) intermingled with $\mathrm{CD} 11 \mathrm{c}^{+}$DCs, and regulatory Foxp $3^{+}$ $\mathrm{T}$ cells (Fig. 5b, c). Proliferating $\mathrm{Ki}-67^{+}$cells were detected within the B cell-rich area (Fig. $5 \mathrm{~d}$ ), and in some organized tertiary lymphoid tissues, GC-like structures were additionally defined by staining for $\mathrm{CD} 138^{+}$plasma 
cells and/or FDCs (FDCs; Fig. 5e, f). Taken together, chronic $H$. pylori infection triggered the formation of organized tertiary lymphoid tissues with characteristics of conventional secondary lymphoid organs. Most importantly, the development of tertiary lymphoid tissue was strongly suppressed in $\mathrm{CXCR} 5^{-/-}$mice.

Table 1 Gastric histology of Helicobacter pylori-infected mice

\begin{tabular}{|c|c|c|c|c|c|}
\hline Mouse & $\begin{array}{l}\text { Active } \\
(0-3)\end{array}$ & $\begin{array}{l}\text { Chronic } \\
(0-3)\end{array}$ & $\begin{array}{l}\text { No. } \\
\text { of } \\
\text { TLOs }\end{array}$ & $\begin{array}{l}\text { Intraepithelial } \\
\text { lymphocytes }\end{array}$ & $\begin{array}{l}\text { Reactive } \\
\text { epithelial } \\
\text { changes } \\
(0-2)^{\mathrm{a}}\end{array}$ \\
\hline
\end{tabular}

\begin{tabular}{|c|c|c|c|c|c|}
\hline \multicolumn{6}{|l|}{$\mathrm{Wt}$} \\
\hline 1 & 0 & 1 & 2 & - & 1 \\
\hline 2 & 0 & 1 & 0 & - & 1 \\
\hline 3 & 1 & 1 & 2 & - & 2 \\
\hline 4 & 2 & 2 & 3 & - & 2 \\
\hline 5 & 2 & 2 & 3 & - & 2 \\
\hline 6 & 2 & 2 & 3 & + & 2 \\
\hline 7 & 2 & 2 & $5-6^{\mathrm{b}}$ & + & 2 \\
\hline 8 & 2 & 1 & 2 & + & 2 \\
\hline 9 & 2 & 1 & 1 & + & 2 \\
\hline 10 & 2 & 1 & 3 & + & 2 \\
\hline 11 & 3 & 1 & 1 & + & 2 \\
\hline 12 & 1 & 1 & 0 & - & 1 \\
\hline \multicolumn{6}{|l|}{$\mathrm{CXCR}^{-/-}$} \\
\hline 1 & 0 & 1 & 0 & - & 1 \\
\hline 2 & 1 & 1 & 0 & - & 1 \\
\hline 3 & 0 & 1 & 0 & - & 0 \\
\hline 4 & 2 & 1 & 0 & - & 1 \\
\hline 5 & 1 & 1 & 0 & - & 1 \\
\hline 6 & 0 & 1 & 0 & - & 1 \\
\hline 7 & 2 & 2 & $1^{\mathrm{c}}$ & + & 2 \\
\hline 8 & 0 & 0 & 0 & - & 0 \\
\hline 9 & 0 & 1 & 0 & - & 1 \\
\hline 10 & 3 & 2 & $1^{\mathrm{c}}$ & + & 2 \\
\hline 11 & 0 & 1 & 0 & - & 2 \\
\hline 12 & 0 & 1 & 0 & - & 2 \\
\hline 13 & 0 & 1 & 0 & - & 2 \\
\hline Significance & $*$ & NS & $* *$ & NS & * \\
\hline
\end{tabular}

$0=$ absent, $1=$ mild, $2=$ moderate, $3=$ marked

- normal lymphocytic infiltration, + enhanced lymphocytic infiltrates $(>25$ IEL/100 epithelial cells), NS nonsignificant

$* P<0.05$ (indicates statistical significance); $* * P<0.01$ (indicates statistical significance)

${ }^{\mathrm{a}} 0$, no changes; 1 , epithelial regeneration or epithelial hyperplasia; 2 , epithelial regeneration+epithelial hyperplasia

${ }^{\mathrm{b}}$ SLOs plus GC

${ }^{\mathrm{c}}$ Unorganized lymphoid aggregate
T cell-mediated immune responses to $H$. pylori are partially impaired in $H$. pylori-infected $\mathrm{CXCR}^{-/-}$mice

The development of a Th1-predominant immune response with production of IFN- $\gamma$ has been observed in humans and mice following infection with Helicobacter [28-30]. In addition, the Th17 cytokine IL-17A has been reported to play an important role in mucosal immune responses to Helicobacter infection [31, 32]. Here, we tested if enhanced IFN- $\gamma$, IL-17A, and IL-22 production was detectable in response to chronic infection with $H$. pylori and if the production of inflammatory mediators is altered by CXCR5 deficiency. Serum IFN- $\gamma$ levels of chronically infected mice were below the detection limit of our ELISA. Serum levels of IL-17A were generally elevated after Helicobacter infection, but this increase was not significantly altered in $\mathrm{CXCR}^{-1-}$ compared to Wt mice (data not shown). Next, we used single-cell suspensions from spleens and mLNs of infected mice and restimulated them with $H$. pylori antigen in vitro. Splenocytes and mLN-derived lymphocytes from $\mathrm{Wt}$ and $\mathrm{CXCR}^{-/-}$mice were equally capable of producing IFN- $\gamma$ in response to $H$. pylori sonicate 7 months after infection (Fig. 6a). This suggests that both mouse strains are capable of mounting a Th1-type cellular response to $H$. pylori infection. In addition, splenocytes and mLN-derived cells from infected $\mathrm{Wt}$ mice also produced increased IL17A levels compared to non-infected Wt mice. IL-17A concentrations produced in splenocytes derived from infected $\mathrm{CXCR}^{-/}$mice were comparable to $\mathrm{Wt}$ cells, whereas IL-17A production in $\mathrm{mLN}$-derived cells from infected $\mathrm{CXCR} 5^{-/-}$mice was significantly decreased in response to $H$. pylori sonicate compared to $\mathrm{Wt}$ cells (Fig. 6b). We also found that CXCR5 deficiency altered Helicobacter-induced production of IL-22, another Th17derived cytokine, in mLN-derived cells (Fig. 6c, left panel). Gastrointestinal immune responses directed against mucosal pathogens are predominantly induced in the mucosal associated lymphoid organs, i.e., Peyer's patches (PPs) and mLNs [33]. Hence, Helicobacter-induced cytokine production was generally more prominent in lymphocytes derived from mesenteric LNs than from the spleen, except for IL22. Overall, CXCR5 expression seems to influence Th17but not Th1-type cellular immune responses to $H$. pylori infection.

H. pylori-specific serum IgA and IgG levels are decreased in $\mathrm{CXCR}^{-/-}$mice

Next, we examined whether CXCR5 deficiency influenced the production of anti-H. pylori-specific antibodies. Serum samples from $\mathrm{Wt}$ and $\mathrm{CXCR}^{-1-}$ mice were taken 4 (data not shown) and 7 months after $H$. pylori infection, and antiH. pylori IgG and IgA titers were determined by ELISA. 

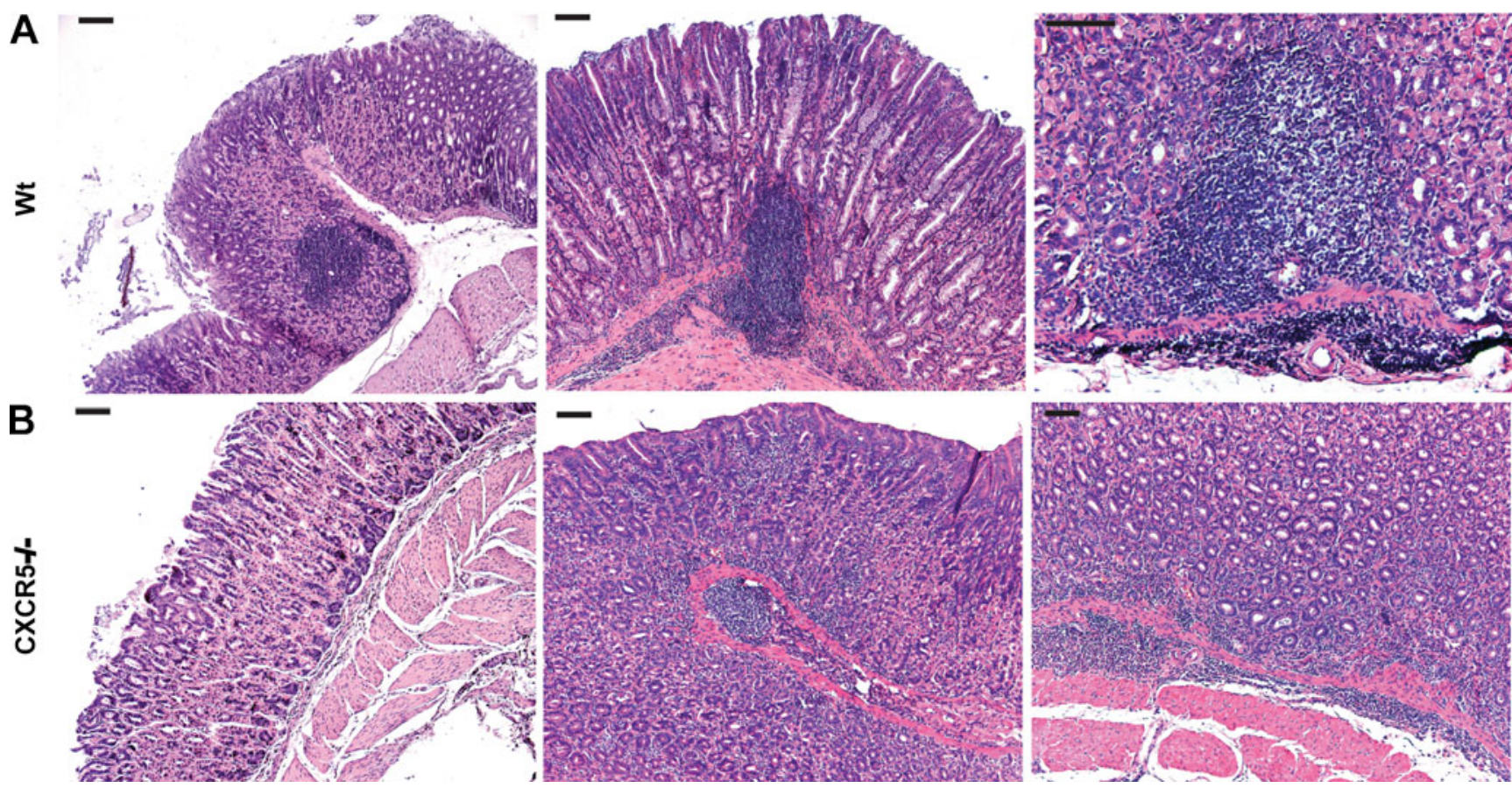

Fig. 2 Helicobacter pylori-induced formation of ectopic lymphoid follicles in Wt but not in CXCR5 $5^{-/-}$mice. Hematoxylin-eosin stainings of paraffin-embedded gastric mucosal tissue sections of three representative H. pylori-infected Wt mice (a) and $\mathrm{CXCR}^{-/-}$mice (b) 5-
17 months after infection. Eleven out of $13 \mathrm{CXCR}^{-/-}$mice completely lacked lymphoid aggregates (one representative example, left panel), and two $\mathrm{CXCR}^{--}$mice showed loose inflammatory aggregates (middle and right panel). Scale bars, $100 \mu \mathrm{m}$
The majority of $H$. pylori-infected Wt mice mounted a strong anti-H. pylori response in comparison to uninfected controls (Fig. 7a, b). In contrast, Helicobacter-specific IgA and $\mathrm{IgG}$ levels were strongly reduced in infected CXCR $5^{-/-}$ mice (Fig. 7a, b) compared to infected Wt mice. Basal serum levels for the same subclasses of immunoglobulin are known to be comparable in both groups [23, 34]. In addition, comparable antigen-specific Ig levels of the various subclasses are observed in DNP-KLH-immunized $\mathrm{CXCR}^{-/-}$and Wt mice [23]. Thus, we conclude that impaired generation of Helicobacter-specific antibodies is not caused by a general inability of $\mathrm{CXCR5^{-/ }}$ mice to mount antigen-specific Ig responses to $\mathrm{T}$ cell-dependent antigens.

\section{Discussion}

In the present study, we provide direct evidence for a pivotal role of CXCR5 in the formation of tertiary lymphoid tissue during Helicobacter-induced chronic gastritis.

A decade ago, it was demonstrated that the ligand for CXCR5 and CXCL13 is highly expressed in gastric lymphoid follicles and in MALT lymphomas of patients with chronic gastritis induced by H. pylori infection [20].
Additional clinical studies have correlated CXCL13/CXCR5 expression with infection-dependent formation of gastric MALT and MALT lymphomas [21, 35]. In experimental mouse models, i.e., chronic experimental tuberculosis and Helicobacter-induced chronic gastritis, formation of lymphoid structures was observed accompanied by expression of the homeostatic chemokine CXCL13, but also CCL19 and CCL21 [17, 18, 22, 36]. However, a genetic in vivo model that would causally link the CXCL13/CXCR5 signaling axis to the pathology of $H$. pylori infection has not yet been described. Here, we employ $\mathrm{CXCR} 5^{-/-}$mice to study CXCR5-dependent formation of tertiary lymphoid tissues during chronic $H$. pylori infection. We show that the CXCL13/CXCR5 signaling axis is crucial for the development of tertiary lymphoid tissues during $H$. pylori-induced gastric inflammation. Five to seven months post-Helicobacter instillation, Wt mice developed a chronic H. pylori infection accompanied by the formation of highly organized and fully functional ectopic lymphoid follicles. Strikingly, CXCR5 $5^{-/-}$mice failed to develop organized ectopic lymphoid follicles. This impaired tertiary lymphoid tissue formation may be associated with changes in the severity and maintenance of chronic inflammation.

The majority of infected Wt animals developed an active chronic gastritis with increased intraepithelial lymphocyte 
Fig. 3 Reduced mucosal proliferation and reactive epithelial changes in Helicobacter pyloriinfected CXCR5 ${ }^{-/-}$mice. a Mucosal proliferation is indicated by Ki67-staining in red (indicated by an arrow). A lower (upper panels) and higher magnification (lower panels) of each group is shown; scale bars, $100 \mu \mathrm{m}$. b Reactive epithelial changes including epithelial hyperplasia and epithelial regeneration were semi-quantitated using a score of 0-2. The black bar indicates the mean of Wt $(n=12)$, and the gray bar the mean of CXCR $5^{-/-}$ $(n=13)$ mice. Statistically significant differences between Wt and $\mathrm{CXCR} 5^{-/-}$mice are indicated by asterisks; $* P<0.05$; unpaired Student's $t$ test

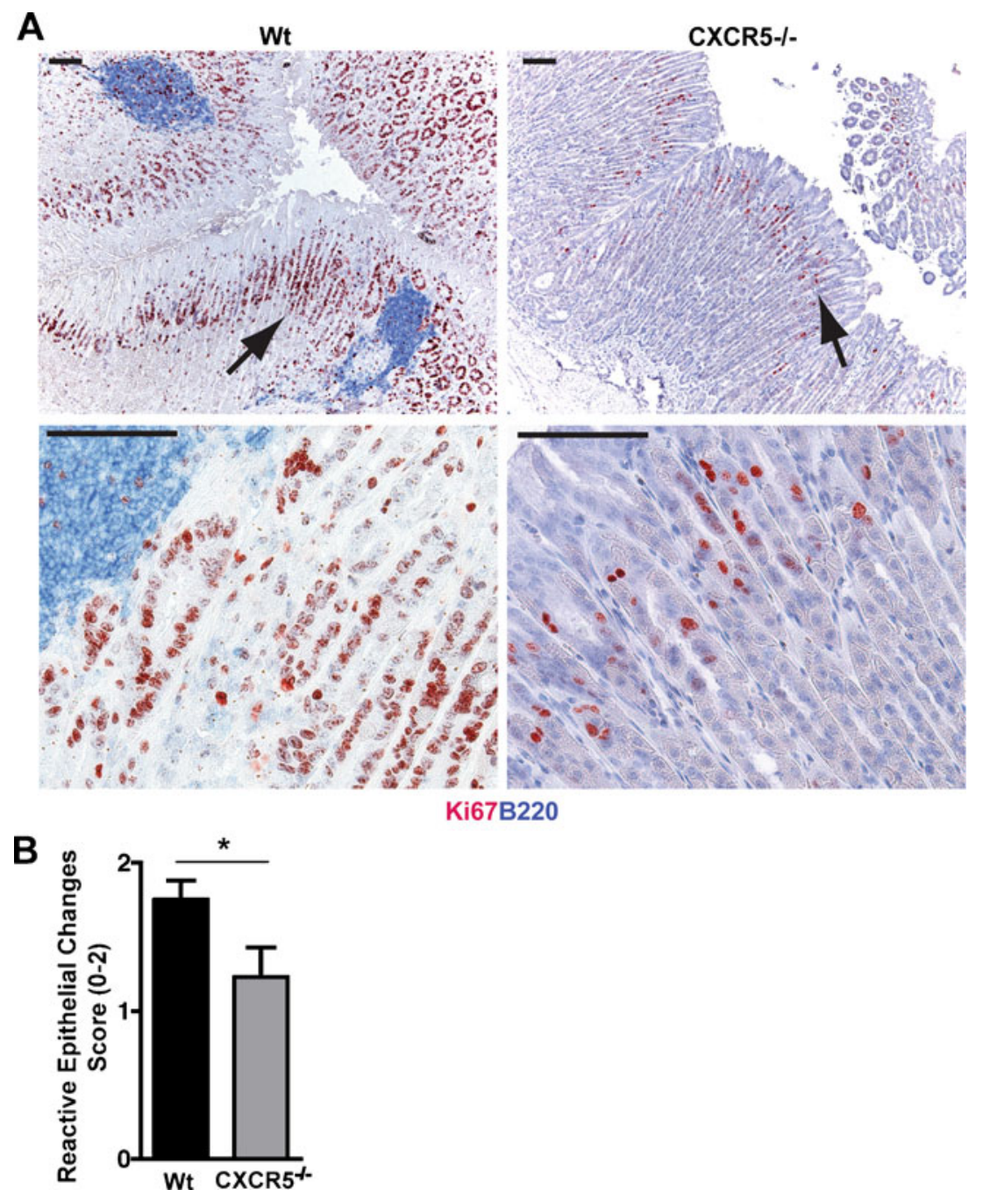

infiltration, increased epithelial proliferation, and gastric atrophy. In contrast, $\mathrm{CXCR} 5^{-/-}$mice showed a reduced gastric inflammation, decreased epithelial proliferation, and subsequently less reactive epithelial pathomorphological changes. This observation is consistent with our previous work using a model of chronic antigen-induced rheumatoid arthritis showing that CXCR5 deficiency leads to a reduction of acute inflammatory parameters, significantly reduced numbers of tertiary lymphoid follicles, and reduced joint destruction [9]. Thus, we have been able to demonstrate CXCR5-dependent formation of tertiary lymphoid tissue and their association with local aberrant chronic immune responses in two independent inflammatory disease models.

Since B cell homing, the development of PPs and some peripheral LNs, as well as GC formation, is generally impaired in these mice [23], reduced inflammation in $\mathrm{CXCR}^{-/-}$mice might also be explained by an impaired induction of secondary immune responses. However, comparable bacterial burdens in $\mathrm{Wt}$ and $\mathrm{CXCR} 5^{-/}$mice suggest that susceptibility to $H$. pylori infection was not altered by CXCR5 deficiency and that $\mathrm{CXCR} 5^{-/-}$mice are still able of mounting an anti-H. pylori immune response. This conclusion is supported by the capability of both, $\mathrm{Wt}$ and $\mathrm{CXCR}^{-/-}$mice, to develop a Th1-like response towards $H$. pylori with production of IFN- $\gamma$. IFN- $\gamma$ has been described as a key cytokine for Th1 cell-mediated immune responses in the control of Helicobacter infection [28-30, 37]. It induces phagocytosis by neutrophils and microbicidal activity and augments the antigen-presenting activity of macrophages and DCs. Although multiple cell types can produce IFN- $\gamma$, its secretion by $\mathrm{CD}^{+}$Th1 cells seems to be crucial for bacterial clearance [38]. Consistent with previous studies [29, 30, 37], we found that lymphocytes and splenocytes from $H$. pylori-infected $\mathrm{Wt}$ or $\mathrm{CXCR}^{-/-}$mice produced the Th1-cytokine IFN- $\gamma$ when they were restimulated with $H$. pylori sonicate in vitro. However, IFN- $\gamma$ can play a dual role in the pathology of Helicobacter infection: IFN- $\gamma$ - and interferon regulatory factor 1-deficient mice show less gastric inflammation and 
Fig. 4 Lack of segregated ectopic follicular tissue formation in $\mathrm{CXCR}^{-/-}$compared to $\mathrm{Wt}$ mice. Paraffin sections with ectopic lymphoid follicles of two representative Wt (a) and sections with loose lymphoid aggregates of two $\mathrm{CXCR} 5^{-1}$ mice (b) 5-17 months after infection were immunohistochemically stained for B (B220 in red) and $\mathrm{T}$ (CD3 in blue) cells, for macrophages (F4/80 in red) and B cells (B220 in blue), and for blood vessel formation (CD31 in red, indicated by arrows) and B cells (B220 in blue). Scale bars, $100 \mu \mathrm{m}$
A

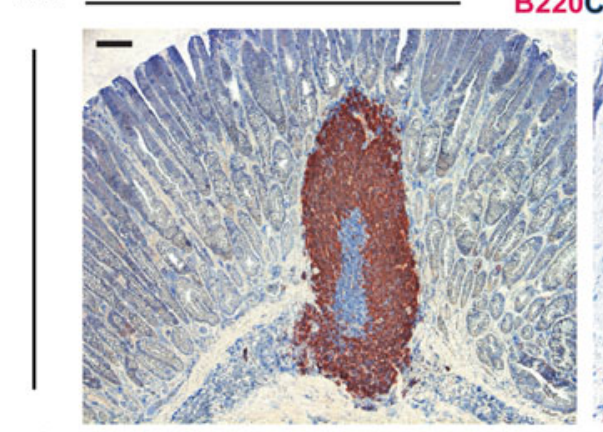

范
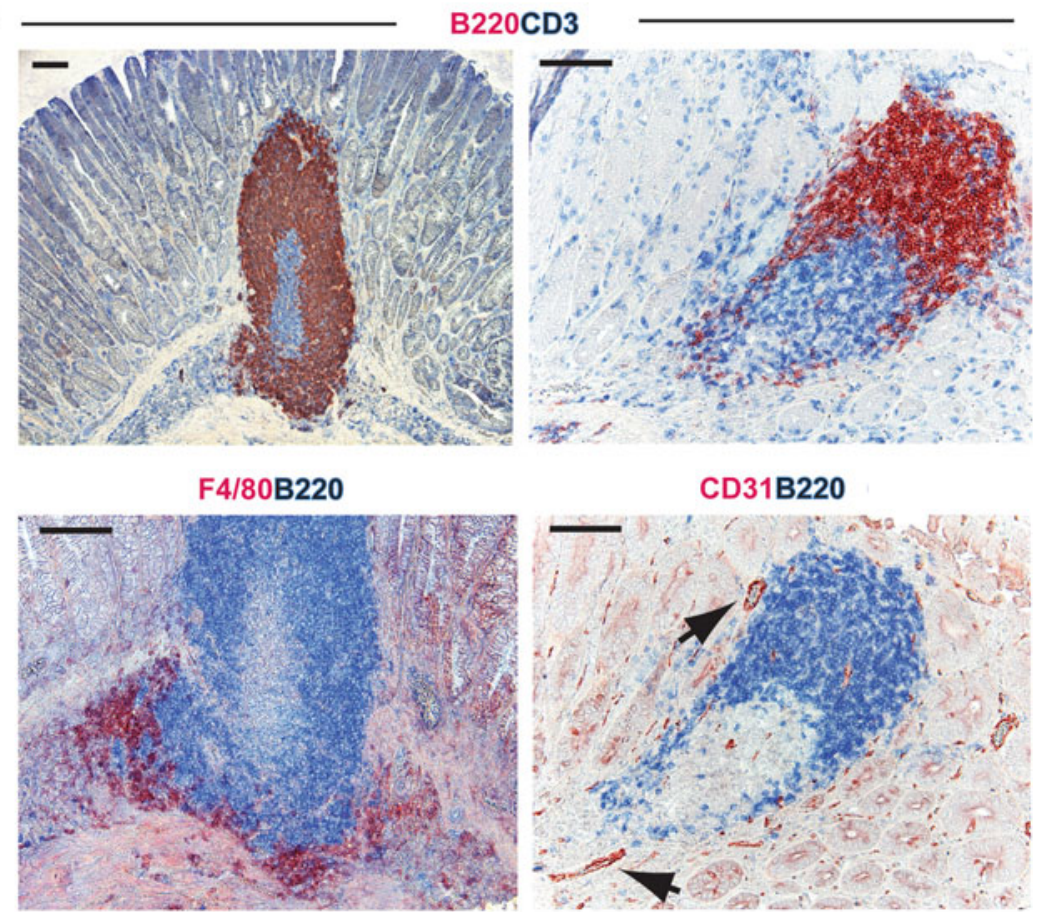

$\mid$

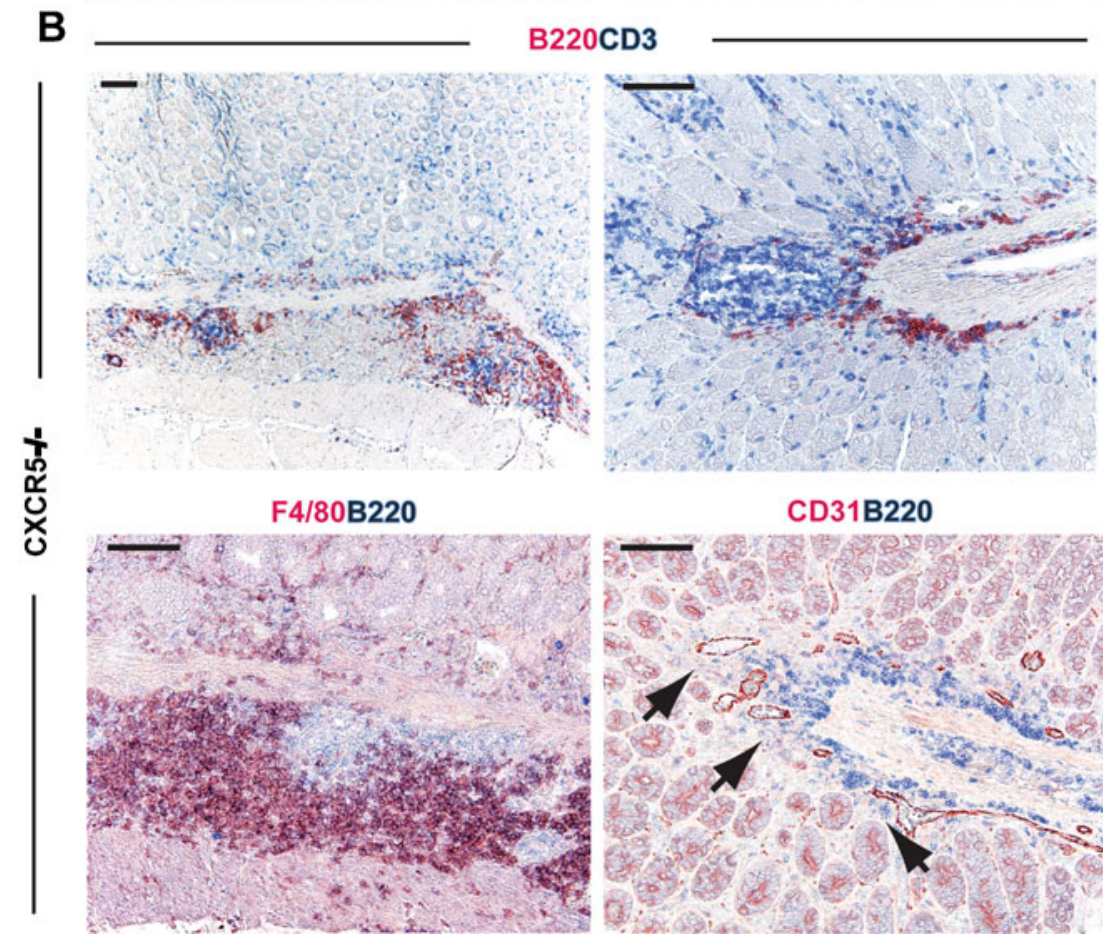

enhanced colonization with $H$. pylori, suggesting that while IFN- $\gamma$ is known to protect against $H$. pylori infection by limiting bacterial growth, upregulation of IFN- $\gamma$ can promote chronic gastric inflammation [29, 30, 37]. Here, we showed that the IFN- $\gamma$-mediated Th1 response during the chronic phase of infection is not significantly altered by the lack of CXCR5.
More recently, another proinflammatory cytokine, IL$17 \mathrm{~A}$, has been proposed to exert an important role in anti-Helicobacter mucosal immune responses as well [39]. In several mouse models, it was shown that the host's ability to kill invading pathogens is partially dependent on the IL-23/IL-17 axis [39-41]. In our model, a Th17 response was also elicited. Cells cultured from the mLNs 
Fig. 5 Mucosal tertiary lymphoid tissues in WT mice exhibit lymph node-like structures. Paraffin sections with ectopic lymphoid follicles of representative Wt mice were immunohistochemically stained for the formation of HEVs (PNAd, peripheral lymph node addressin, in red, indicated by arrows; a), regulatory T cells (Foxp3 in red; c), lymphocytic proliferation (Ki67 in red; d), together with B220 staining (in blue) for B cells and plasma cells (CD138 in red, indicated by an arrow; e). Scale bars, $100 \mu \mathrm{m}$. Immunofluorescence and immunohistochemical stainings of frozen sections show CD $11 \mathrm{c}^{+}$DCs (in blue) scattered within the $\mathrm{T}$ cell zone $\left(\mathrm{CD}^{+}{ }^{+} \mathrm{T}\right.$ cells in green; $\left.\mathbf{b}\right)$ and FDCs (in red) located within the B cell follicle (f). Scale bar, $100 \mu \mathrm{m}$

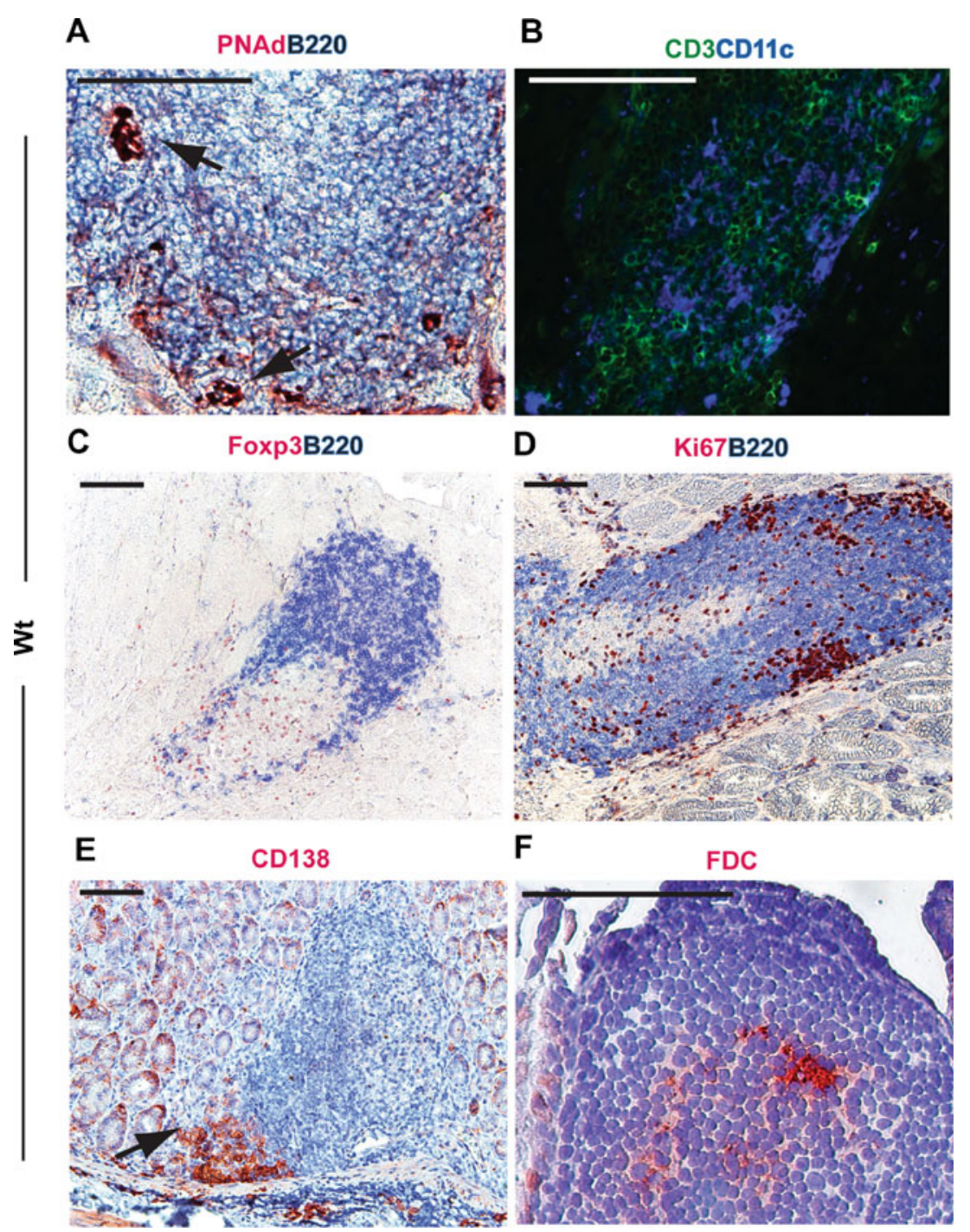

of Wt mice expressed increased IL-17A levels after in vitro restimulation with $H$. pylori sonicate in comparison to uninfected controls. In contrast, cells from the mLNs of infected $\mathrm{CXCR} 5^{-/-}$mice showed almost no increase in IL17A levels. This suggests that CXCR5 deficiency alters IL-17-producing $\mathrm{T}$ cell responses upon $H$. pylori infection. The effect of IL-17A on Helicobacter-induced immune responses remains unclear. Recent work has shown that deletion of the IL-17 gene inhibited $H$. pylori-induced gastritis [42]. In contrast, Ab-mediated neutralization of IL-17A [43] or blockage of IL-17RA signaling by employing IL-17RA-deficient mice [44] led to an upregulation of chronic mononuclear inflammation elicited by $H$. pylori infection. IL-17RA-deficient mice also exhibited elevated mucosal levels of the $B$ cell chemoattractant CXCL13. It was suggested that increased CXCL13 levels cause the accelerated B cell-predominant chronic inflammation in the IL-17RA-deficient mice [44].
In our study, decreased expression of IL-17A in the $\mathrm{CXCR}^{-/-}$mice was not associated with increased mononuclear infiltration. Because CXCL13/CXCR5mediated effects are blocked in the $\mathrm{CXCR}^{-/-}$mice, our findings are not mutually exclusive to the data of Algood et al.

A striking difference between $\mathrm{Wt}$ and $\mathrm{CXCR} 5^{-/-}$mice was seen in $H$. pylori-specific serum $\operatorname{IgG}$ and $\operatorname{IgA} \mathrm{Ab}$ responses 4 and 7 months after infection. Wt mice mounted a strong anti-H. pylori IgA and IgG Ab response, whereas the majority of $\mathrm{CXCR} 5^{-/}$mice showed only weak anti- $H$. pylori IgA and IgG Ab titers. Basal serum levels for the same subclasses of immunoglobulin were comparable for non-infected $\mathrm{CXCR} 5^{-1-}$ and $\mathrm{Wt}$ mice as described earlier [23, 34]. Additionally, CXCR5 ${ }^{-/-}$mice exhibited normal levels of switched Ig isotypes after immunization with DNP-keyhole limpet hemocyanin [23]. More recently, the impact of CXCR5 on antiviral B 
A
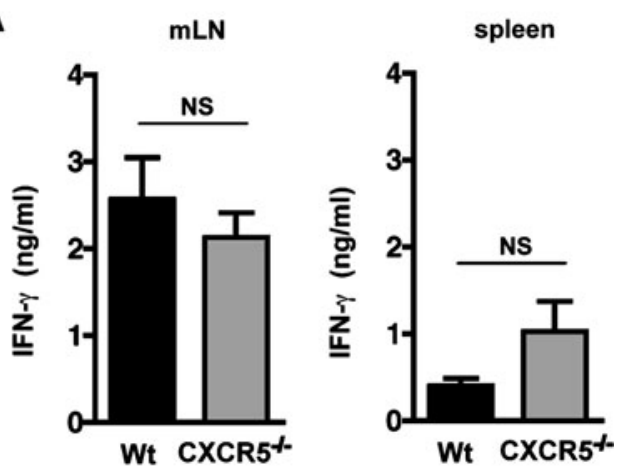

B

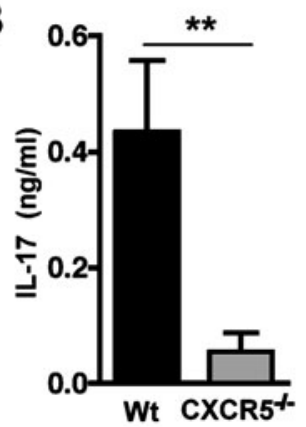

C
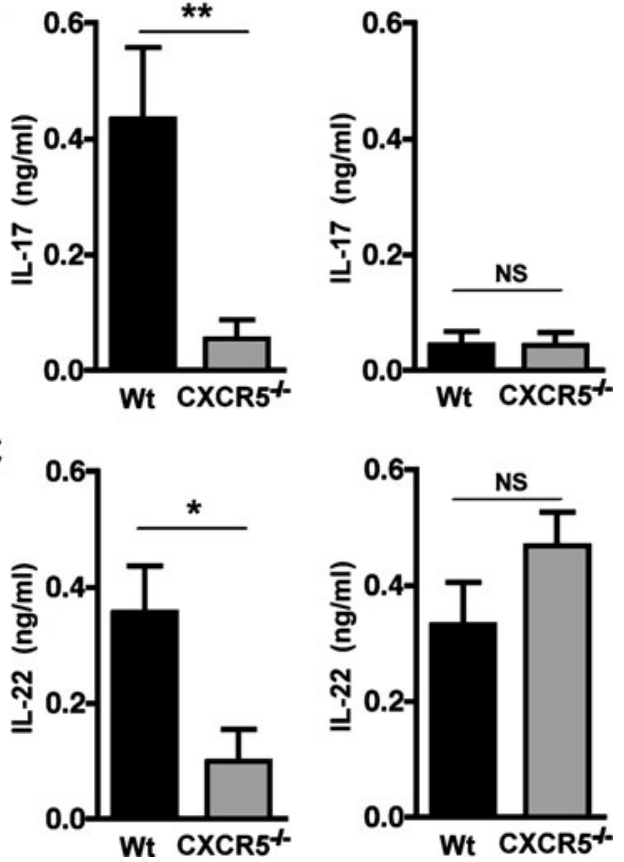

Fig. 6 Helicobacter pylori-specific Th17 cell proliferation was reduced, but the Th1 responses were unaltered in $\mathrm{CXCR} 5^{-/}$mice. Seven months after infection, cell suspensions from mesenteric LNs and spleens of Wt (black bars; $n=6-7$ ) and CXCR $5^{-1}$ mice (gray bars; $n=6-7)$ were restimulated in vitro $\left(1 \times 10^{6}\right.$ cells $)$ with or without H. pylori sonicate $(100 \mu \mathrm{g} / \mathrm{ml})$ for $72 \mathrm{~h}$. Undiluted supernatants were analyzed for IFN- $\gamma$ (a), IL-17A (b), and IL-22 (c) by ELISA. The mean cytokine release from cells of non-infected Wt mice $(n=3)$ and $\mathrm{CXCR}^{-1-}$ mice $(n=3)$ was subtracted from each individual-infected animal. Bars represent the arithmetic means \pm SEM. ${ }^{*} P<0.05$ and $* * P<0.01$; unpaired Mann-Whitney test

cell responses was assessed. $\mathrm{CXCR} 5^{-/}$mice produced normal levels of neutralizing IgM and IgG Abs in an acute infection with vesicular stomatitis virus (VSV) and also developed VSV-specific GCs [45]. However, under conditions of limited antigenic doses, humoral antiviral B cell responses were significantly reduced in $\mathrm{CXCR}^{-/-}$mice due to impaired Ag-specific expansion of $\mathrm{B}$ cells in secondary lymphoid organs and impaired recruitment of Ag-specific B and Th cells to GCs [45]. Recently, it has been demonstrated that $H$. pylori is predominantly
A

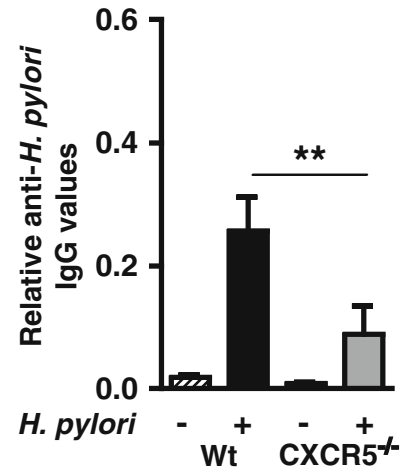

B

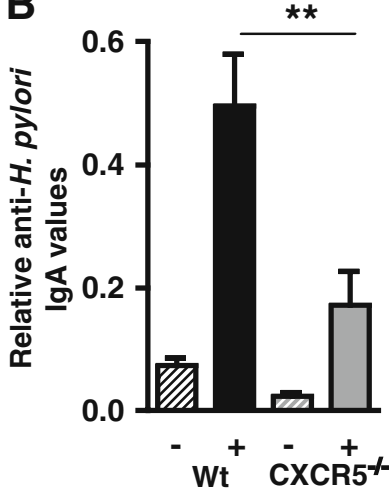

Fig. 7 Decreased serum levels of anti-Helicobacter pylori-specific $\mathrm{IgG}$ and $\mathrm{IgA}$ in $\mathrm{CXCR} 5^{-/-}$mice. a Six to seven months after infection, blood sera from Wt (black bar; $n=17$ ) and CXCR $5^{-1-}$ mice (gray bar; $n=18$ ) were analyzed for the presence of $H$. pylori-specific IgG (a) and IgA (b) Abs by ELISA. Non-infected Wt (hatched black bar; $n=$ 5) and $\mathrm{CXCR}^{-1-}$ mice (hatched gray bar; $n=5$ ) served as controls. Sera were diluted 1:500 for IgA and 1:400 for IgG measurements, and the absorbance at $450 \mathrm{~nm}$ represents the relative anti-H. pylori IgG or IgA value. Data represent the arithmetic means \pm SEM of two independent experiments. ${ }^{* *} P<0.01$, unpaired Mann-Whitney test

phagocytosed by DCs in PPs but not in the gastric lamina propria or gastric epithelium [46, 47]. Subsequently, $H$. pylori antigen-specific $\mathrm{CD} 4^{+} \mathrm{T}$ cells are primed in PPs and in $\mathrm{mLNs}$. Since $\mathrm{CXCR5^{-1- }}$ mice have severely reduced numbers of PPs, one could envisage that less antigenloaded DCs are generated which could eventually reach the $\mathrm{mLN}$ for the priming of $\mathrm{T}$ cells. Under such circumstances, lack of CXCR5 might lead to impaired efficacy of T cell-dependent B cell responses against Helicobacter-infection, resulting in a reduced anti-Helicobacter humoral response. In addition, reduced antigenic priming within the mLNs might also influence IL-17A and IL-22 production in mLN-derived cells of infected $\mathrm{CXCR} 5^{-/}$mice.

In summary, our data indicate that CXCR5 crucially regulates the formation of organized ectopic lymphoid follicles during chronic $H$. pylori-induced gastritis. Lack of tertiary lymphoid tissue development is additionally accompanied by reduced chronic gastric inflammation. We propose that CXCR5 is a promising therapeutic target in chronic inflammation not only associated with autoimmune diseases but also during chronic infectious diseases.

Acknowledgments We are grateful to Kerstin Krüger and Heike Schwede for expert technical assistance. We are indebted to Armin Rehm for helpful suggestions and critical reading of the manuscript. The authors thank Markus M. Heimesaat and Andre Fischer for their help with the housing of Helicobacter-infected mice. This research was supported by the Priority Program SFB 633 of the German Research Foundation (DFG) and partially by the Deutsche Krebshilfe e.V.

Disclosure statement All authors do not have a commercial or other association that might pose a conflict of interest. 
Open Access This article is distributed under the terms of the Creative Commons Attribution Noncommercial License which permits any noncommercial use, distribution, and reproduction in any medium, provided the original author(s) and source are credited.

\section{References}

1. Ansel KM, Ngo VN, Hyman PL, Luther SA, Forster R, Sedgwick JD, Browning JL, Lipp M, Cyster JG (2000) A chemokine-driven positive feedback loop organizes lymphoid follicles. Nature 406:309-314. doi:10.1038/35018581

2. Cyster JG (2003) Lymphoid organ development and cell migration. Immunol Rev 195:5-14. doi:075

3. Muller G, Hopken UE, Lipp M (2003) The impact of CCR7 and CXCR5 on lymphoid organ development and systemic immunity. Immunol Rev 195:117-135. doi:073

4. Manzo A, Paoletti S, Carulli M, Blades MC, Barone F, Yanni G, Fitzgerald O, Bresnihan B, Caporali R, Montecucco C, Uguccioni M, Pitzalis C (2005) Systematic microanatomical analysis of CXCL13 and CCL21 in situ production and progressive lymphoid organization in rheumatoid synovitis. Eur J Immunol 35:13471359. doi:10.1002/eji.200425830

5. Manzo A, Vitolo B, Humby F, Caporali R, Jarrossay D, Dell'accio F, Ciardelli L, Uguccioni M, Montecucco C, Pitzalis C (2008) Mature antigen-experienced $\mathrm{T}$ helper cells synthesize and secrete the B cell chemoattractant CXCL13 in the inflammatory environment of the rheumatoid joint. Arthritis Rheum 58:3377-3387. doi:10.1002/art.23966

6. Amft N, Curnow SJ, Scheel-Toellner D, Devadas A, Oates J, Crocker J, Hamburger J, Ainsworth J, Mathews J, Salmon M, Bowman SJ, Buckley CD (2001) Ectopic expression of the B cellattracting chemokine BCA-1 (CXCL13) on endothelial cells and within lymphoid follicles contributes to the establishment of germinal center-like structures in Sjogren's syndrome. Arthritis Rheum 44:2633-2641

7. Salomonsson $S$, Larsson $P$, Tengner P, Mellquist E, Hjelmstrom $P$, Wahren-Herlenius M (2002) Expression of the B cell-attracting chemokine CXCL13 in the target organ and autoantibody production in ectopic lymphoid tissue in the chronic inflammatory disease Sjogren's syndrome. Scand J Immunol 55:336-342. doi: 1058

8. Serafini B, Rosicarelli B, Magliozzi R, Stigliano E, Aloisi F (2004) Detection of ectopic B-cell follicles with germinal centers in the meninges of patients with secondary progressive multiple sclerosis. Brain Pathol 14:164-174

9. Wengner AM, Hopken UE, Petrow PK, Hartmann S, Schurigt U, Brauer R, Lipp M (2007) CXCR5- and CCR7-dependent lymphoid neogenesis in a murine model of chronic antigeninduced arthritis. Arthritis Rheum 56:3271-3283. doi:10.1002/ art.22939

10. Fan L, Reilly CR, Luo Y, Dorf ME, Lo D (2000) Cutting edge: ectopic expression of the chemokine TCA4/SLC is sufficient to trigger lymphoid neogenesis. J Immunol 164:3955-3959. doi: ji v164n8p3955

11. Luther SA, Lopez T, Bai W, Hanahan D, Cyster JG (2000) BLC expression in pancreatic islets causes B cell recruitment and lymphotoxin-dependent lymphoid neogenesis. Immunity 12:471481. doi:S1074-7613(00)80199-5

12. Marinkovic T, Garin A, Yokota Y, Fu YX, Ruddle NH, Furtado GC, Lira SA (2006) Interaction of mature CD3+CD4+ T cells with dendritic cells triggers the development of tertiary lymphoid structures in the thyroid. J Clin Invest 116:2622-2632. doi:10.1172/JCI28993
13. Martin AP, Coronel EC, Sano G, Chen SC, Vassileva G, CanastoChibuque C, Sedgwick JD, Frenette PS, Lipp M, Furtado GC, Lira SA (2004) A novel model for lymphocytic infiltration of the thyroid gland generated by transgenic expression of the CC chemokine CCL21. J Immunol 173:4791-4798. doi:173/8/4791

14. Steere AC, Duray PH, Butcher EC (1988) Spirochetal antigens and lymphoid cell surface markers in Lyme synovitis. Comparison with rheumatoid synovium and tonsillar lymphoid tissue. Arthritis Rheum 31:487-495

15. Hillan KJ, Hagler KE, MacSween RN, Ryan AM, Renz ME, Chiu HH, Ferrier RK, Bird GL, Dhillon AP, Ferrell LD, Fong S (1999) Expression of the mucosal vascular addressin, MAdCAM-1, in inflammatory liver disease. Liver 19:509-518

16. Yoneyama $\mathrm{H}$, Matsuno $\mathrm{K}$, Zhang $\mathrm{Y}$, Murai $\mathrm{M}$, Itakura $\mathrm{M}$, Ishikawa S, Hasegawa G, Naito M, Asakura H, Matsushima K (2001) Regulation by chemokines of circulating dendritic cell precursors, and the formation of portal tract-associated lymphoid tissue, in a granulomatous liver disease. J Exp Med 193:35-49

17. Kahnert A, Hopken UE, Stein M, Bandermann S, Lipp M, Kaufmann SH (2007) Mycobacterium tuberculosis triggers formation of lymphoid structure in murine lungs. J Infect Dis 195:46-54. doi:10.1086/508894/JID36791

18. Schreiber T, Ehlers S, Aly S, Holscher A, Hartmann S, Lipp M, Lowe JB, Holscher C (2006) Selectin ligand-independent priming and maintenance of $\mathrm{T}$ cell immunity during airborne tuberculosis. J Immunol 176:1131-1140. doi:176/2/1131

19. Dogan A, Du M, Koulis A, Briskin MJ, Isaacson PG (1997) Expression of lymphocyte homing receptors and vascular addressins in low-grade gastric B-cell lymphomas of mucosa-associated lymphoid tissue. Am J Pathol 151:1361-1369

20. Mazzucchelli L, Blaser A, Kappeler A, Scharli P, Laissue JA, Baggiolini M, Uguccioni M (1999) BCA-1 is highly expressed in Helicobacter pylori-induced mucosa-associated lymphoid tissue and gastric lymphoma. J Clin Invest 104:R49-R54. doi:10.1172/ JCI7830

21. Barone F, Bombardieri M, Rosado MM, Morgan PR, Challacombe SJ, De Vita S, Carsetti R, Spencer J, Valesini G, Pitzalis C (2008) CXCL13, CCL21, and CXCL12 expression in salivary glands of patients with Sjogren's syndrome and MALT lymphoma: association with reactive and malignant areas of lymphoid organization. J Immunol 180:5130-5140. doi:180/7/5130

22. Shomer NH, Fox JG, Juedes AE, Ruddle NH (2003) Helicobacter-induced chronic active lymphoid aggregates have characteristics of tertiary lymphoid tissue. Infect Immun 71:3572-3577

23. Forster R, Mattis AE, Kremmer E, Wolf E, Brem G, Lipp M (1996) A putative chemokine receptor, BLR1, directs B cell migration to defined lymphoid organs and specific anatomic compartments of the spleen. Cell 87:1037-1047. doi:S0092-8674 (00)81798-5

24. Lee A, O'Rourke J, De Ungria MC, Robertson B, Daskalopoulos G, Dixon MF (1997) A standardized mouse model of Helicobacter pylori infection: introducing the Sydney strain. Gastroenterology 112:1386-1397. doi:S001650859700190X

25. Velin D, Bachmann D, Bouzourene H, Michetti P (2005) Mast cells are critical mediators of vaccine-induced Helicobacter clearance in the mouse model. Gastroenterology 129:142-155. doi:S001650850500692X

26. Hayat M, Arora DS, Dixon MF, Clark B, O'Mahony S (1999) Effects of Helicobacter pylori eradication on the natural history of lymphocytic gastritis. Gut 45:495-498

27. Dixon MF, Genta RM, Yardley JH, Correa P (1996) Classification and grading of gastritis. The updated Sydney System. International Workshop on the Histopathology of Gastritis, Houston 1994. Am J Surg Pathol 20:1161-1181 
28. Bamford KB, Fan X, Crowe SE, Leary JF, Gourley WK, Luthra GK, Brooks EG, Graham DY, Reyes VE, Ernst PB (1998) Lymphocytes in the human gastric mucosa during Helicobacter pylori have a $\mathrm{T}$ helper cell 1 phenotype. Gastroenterology 114:482-492. doi:S0016508598002170

29. Smythies LE, Waites KB, Lindsey JR, Harris PR, Ghiara P, Smith PD (2000) Helicobacter pylori-induced mucosal inflammation is Th1 mediated and exacerbated in IL-4, but not IFNgamma, gene-deficient mice. J Immunol 165:1022-1029. doi: ji_v165n2p1022

30. Sommer F, Faller G, Rollinghoff M, Kirchner T, Mak TW, Lohoff M (2001) Lack of gastritis and of an adaptive immune response in interferon regulatory factor-1-deficient mice infected with Helicobacter pylori. Eur J Immunol 31:396-402. doi:10.1002/15214141(200102)31:2<396::AID-IMMU396>3.0.CO;2-Y

31. Furuzawa-Carballeda J, Vargas-Rojas MI, Cabral AR (2007) Autoimmune inflammation from the Th17 perspective. Autoimmun Rev 6:169-175. doi:10.1016/j.autrev.2006.10.002/S15689972(06)00169-8

32. McKenzie BS, Kastelein RA, Cua DJ (2006) Understanding the IL-23-IL-17 immune pathway. Trends Immunol 27:17-23. doi:10.1016/j.it.2005.10.003/S1471-4906(05)00281-4

33. Brandtzaeg P, Bjerke K, Kett K, Kvale D, Rognum TO, Scott H, Sollid LM, Valnes K (1987) Production and secretion of immunoglobulins in the gastrointestinal tract. Ann Allergy 59:21-39

34. Hopken UE, Achtman AH, Kruger K, Lipp M (2004) Distinct and overlapping roles of CXCR5 and CCR7 in B-1 cell homing and early immunity against bacterial pathogens. J Leukoc Biol 76:709-718. doi:10.1189/jlb.1203643

35. Mueller A, O'Rourke J, Chu P, Chu A, Dixon MF, Bouley DM, Lee A, Falkow S (2005) The role of antigenic drive and tumorinfiltrating accessory cells in the pathogenesis of helicobacterinduced mucosa-associated lymphoid tissue lymphoma. Am J Pathol 167:797-812. doi:167/3/797

36. Maglione PJ, Xu J, Chan J (2007) B cells moderate inflammatory progression and enhance bacterial containment upon pulmonary challenge with Mycobacterium tuberculosis. J Immunol 178:7222-7234. doi:178/11/7222

37. Sawai N, Kita M, Kodama T, Tanahashi T, Yamaoka Y, Tagawa Y, Iwakura Y, Imanishi J (1999) Role of gamma interferon in Helicobacter pylori-induced gastric inflammatory responses in a mouse model. Infect Immun 67:279-285

38. Sayi A, Kohler E, Hitzler I, Arnold I, Schwendener R, Rehrauer $\mathrm{H}$, Muller A (2009) The CD4+ T cell-mediated IFN-gamma response to Helicobacter infection is essential for clearance and determines gastric cancer risk. J Immunol 182:7085-7101. doi:10.4049/jimmunol.0803293

39. Caruso R, Pallone F, Monteleone G (2007) Emerging role of IL23/IL-17 axis in H. pylori-associated pathology. World J Gastroenterol 13:5547-5551

40. Curtis MM, Way SS, Wilson CB (2009) IL-23 promotes the production of IL-17 by antigen-specific CD8 T cells in the absence of IL-12 and type-I interferons. J Immunol 183:381-387. doi:10.4049/jimmunol.0900939/183/1/381

41. Dubin PJ, Kolls JK (2008) Th17 cytokines and mucosal immunity. Immunol Rev 226:160-171. doi:10.1111/j.1600065X.2008.00703.x/IMR703

42. Shiomi S, Toriie A, Imamura S, Konishi H, Mitsufuji S, Iwakura Y, Yamaoka Y, Ota H, Yamamoto T, Imanishi J, Kita M (2008) IL17 is involved in Helicobacter pylori-induced gastric inflammatory responses in a mouse model. Helicobacter 13:518-524. doi:10.1111/j.1523-5378.2008.00629.x/HEL629

43. Otani $\mathrm{K}$, Watanabe $\mathrm{T}$, Tanigawa $\mathrm{T}$, Okazaki $\mathrm{H}$, Yamagami $\mathrm{H}$, Watanabe K, Tominaga K, Fujiwara Y, Oshitani N, Arakawa T (2009) Anti-inflammatory effects of IL-17A on Helicobacter pylori-induced gastritis. Biochem Biophys Res Commun 382:252-258. doi:10.1016/j.bbrc.2009.02.107/S0006-291X(09) 00380-5

44. Algood HM, Allen SS, Washington MK, Peek RM Jr, Miller GG, Cover TL (2009) Regulation of gastric B cell recruitment is dependent on IL-17 receptor A signaling in a model of chronic bacterial infection. J Immunol 183:5837-5846. doi:10.4049/ jimmunol.0901206

45. Junt T, Fink K, Forster R, Senn B, Lipp M, Muramatsu M, Zinkernagel RM, Ludewig B, Hengartner H (2005) CXCR5dependent seeding of follicular niches by B and Th cells augments antiviral B cell responses. J Immunol 175:7109-7116. doi:175/11/ 7109

46. Nagai S, Mimuro H, Yamada T, Baba Y, Moro K, Nochi T, Kiyono H, Suzuki T, Sasakawa C, Koyasu S (2007) Role of Peyer's patches in the induction of Helicobacter pylori-induced gastritis. Proc Natl Acad Sci USA 104:8971-8976. doi:10.1073/ pnas.0609014104

47. Kiriya K, Watanabe N, Nishio A, Okazaki K, Kido M, Saga K, Tanaka J, Akamatsu T, Ohashi S, Asada M, Fukui T, Chiba T (2007) Essential role of Peyer's patches in the development of Helicobacter-induced gastritis. Int Immunol 19:435-446. doi:10.1093/intimm/dxm008 